\title{
Synthesis, characterization, and POM-protein interactions of a Fe-substituted Krebs-type Sandwich-tungstoantimonate
}

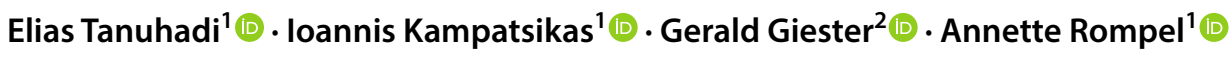

Received: 23 December 2018 / Accepted: 25 January 2019 / Published online: 29 April 2019

(c) The Author(s) 2019

\begin{abstract}
The novel iron-substituted Krebs-type polyoxotungstate $\left(\mathrm{C}_{12} \mathrm{~N}_{4} \mathrm{H}_{11}\right)_{4} \mathrm{Na}_{2} \mathrm{H}_{5}\left[\left(\mathrm{Fe}\left(\mathrm{H}_{2} \mathrm{O}\right)_{3}\right)_{2}\left(\left(\mathrm{FeO}_{2}\right)_{0.5}\left(\mathrm{WO}_{2}\right)_{0.5}\right)_{2}\left(\beta-\mathrm{SbW}_{9} \mathrm{O}_{33}\right)_{2}\right]$ (Fe-1) has been synthesized using ortho-phenylenediamine (opda) as a precursor for the in situ formation of the counter cation 2,3-diaminophenazinium $\left(\mathrm{C}_{12} \mathrm{~N}_{4} \mathrm{H}_{11}\right)^{+}(2,3-\mathrm{DAP})$. Fe-1 has been thoroughly characterized in the solid state by singlecrystal X-ray diffraction (SXRD), powder X-ray diffraction (PXRD), IR spectroscopy, and elemental analysis as well as in solution by UV-Vis spectroscopy. The crystal structure of Fe-1 reveals $\pi-\pi$-interactions between the aromatic systems of the unconventional 2,3-DAP counter cation. POM-protein interaction studies using SDS-PAGE revealed a non-proteolytic behavior of Fe-1 towards Human Serum Albumin (HSA) as a model protein.
\end{abstract}

\section{Graphical abstract}

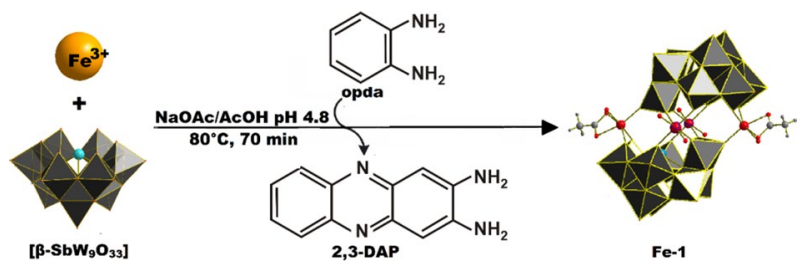

Keywords Sandwich polyoxometalates $\cdot$ Crystal structure $\cdot$ Proteins $\cdot$ Bioinorganic chemistry $\cdot$ Tungstoantimonates

Dedicated to Prof. Dr. Heinz Falk on the occasion of his 80th birthday.

Electronic supplementary material The online version of this article (https://doi.org/10.1007/s00706-019-2381-5) contains supplementary material, which is available to authorized users.

Annette Rompel

annette.rompel@univie.ac.at

http://www.bpc.univie.ac.at

1 Universität Wien, Fakultät für Chemie, Institut für Biophysikalische Chemie, Althanstraße 14, 1090 Wien, Austria

2 Universität Wien, Fakultät für Geowissenschaften, Geographie und Astronomie, Institut für Mineralogie und Kristallographie, Althanstraße 14, 1090 Wien, Austria

\section{Introduction}

Polyoxometalates (POMs) [1] represent a broad class of anionic clusters, which are composed of metal ions in high oxidation states and linked by oxygen atoms resulting in a vast variety of unique structures. Depending on their size, charge, and composition, POM frameworks exhibit numerous different properties opening potential applications in different research fields of catalysis [2], materials science [3], and biological chemistry $[4,5]$ including protein crystallography $[6,7]$.

Among the POM family, transition metal substituted POMs (TMSPs) represent the largest group, mainly counting the subgroup of Sandwich-type POMs. Sandwich-type POMs, which are generally composed of two lacunary building blocks linked by a belt of heteroatoms, can be further divided into various subgroups, among them the Krebs-archetype. 
Krebs-type POMs comprise two lone-pair containing $\beta$-Keggin lacunary fragments, e.g. $\left[\beta-\mathrm{Sb}(\mathrm{III}) \mathrm{W}_{9} \mathrm{O}_{33}\right]^{9-}[8]$. The first representatives of the Krebs-archetype with the general formula $\left[\mathrm{M}_{2}\left(\mathrm{H}_{2} \mathrm{O}\right)_{6}\left(\mathrm{WO}_{2}\right)_{2}\left(\beta-\mathrm{SbW}_{9} \mathrm{O}_{33}\right)_{2}\right]^{(14-2 \mathrm{n})-}\left(\mathrm{M}=\mathrm{Fe}^{3+}, \mathrm{Co}^{2+}\right.$, $\left.\mathrm{Mn}^{2+}, \mathrm{Ni}^{2+}\right)$ were reported by Krebs and co-workers in 1997 [8], exhibiting considerable importance in the fields of both homo- and heterogeneous catalysis [9]. The use of this archetype for the synthesis of new hexagon-type Sandwich POM compounds has recently been reported [10]. As Krebs-type POMs comprise free accessible metal centers, the natural ligand-binding interactions between protein side chains and the peripheral metal centers may be of interest for POM-assisted protein crystallography [11].

Inspired by the use of opda as a precursor for the in situ generation of the unconventional 2,3-DAP counter cation, the novel iron-substituted Krebs-type Sandwich POM $\left(\mathrm{C}_{12} \mathrm{~N}_{4} \mathrm{H}_{11}\right)_{4} \mathrm{Na}_{2} \mathrm{H}_{5}\left[\left(\mathrm{Fe}\left(\mathrm{H}_{2} \mathrm{O}\right)_{3}\right)_{2}\left(\left(\mathrm{FeO}_{2}\right)_{0.5}(\mathrm{~W}-\right.\right.$ $\left.\left.\left.\mathrm{O}_{2}\right)_{0.5}\right)_{2}\left(\beta-\mathrm{SbW}_{9} \mathrm{O}_{33}\right)_{2}\right](\mathbf{F e}-\mathbf{1})$ has been prepared. Herein, we report on the synthesis and thorough characterization of the novel Fe-substituted Krebs-type Sandwich tungstoantimonate Fe-1. Regarding the scarce number of studies on the POM-protein interactions of the Krebs-POM archetype [10] and the potential use of non-proteolytic POM clusters as additives in POM-assisted protein crystallography, the POM-protein interactions of Fe-1 with Human serum albumin (HSA) as a model protein were investigated using SDSPAGE to assess whether Fe-1 shows any proteolytic activity towards HSA.

\section{Results and discussion}

\section{Synthesis of Fe-1}

An aqueous solution of $\mathrm{Na}_{9}\left[\mathrm{SbW}_{9} \mathrm{O}_{33}\right]$ contains a mixture of $\left[\alpha-\mathrm{SbW}_{9} \mathrm{O}_{33}\right]$ and $\left[\beta-\mathrm{SbW}_{9} \mathrm{O}_{33}\right]$ in equilibrium. It is well documented that the latter species $\left[\beta-\mathrm{SbW}_{9} \mathrm{O}_{33}\right]$ dominates the equilibrium at $\mathrm{pH}$ values lower than 6.0 [8]. As a matter of fact, the reaction was carried out in an acetate buffer at $\mathrm{pH}$ 4.8. Upon addition of opda to a warm aqueous acidic reaction mixture of $\mathrm{Na}_{9}\left[\mathrm{SbW}_{9} \mathrm{O}_{33}\right]$ and $\mathrm{FeCl}_{3}$, the initially yellow solution gradually turned dark red indicating the oxidation of opda to 2,3-diaminophenazine (2,3-DAP) catalyzed by the in situ formed Fe-1 Krebs-POM. Cooling of the reaction mixture to room temperature resulted in the formation of dark red crystal plates consisting of polyanion $\mathbf{F e}-\mathbf{1}$ (Scheme 1).

\section{Crystal structure of Fe-1}

Single crystal X-ray diffraction (SXRD) studies were performed on $\mathbf{F e}-\mathbf{1}$ revealing a Krebs-type structure which crystallizes in the triclinic space group P-1. The crystal structure of $\mathbf{F e}-\mathbf{1}$ exhibits two $\left[\beta-\mathrm{SbW}_{9} \mathrm{O}_{33}\right]$ lacunary species linked by two $\mathrm{Fe}(\mathrm{III})$ metal centers at the peripheral sites and two W(VI) centers which show a 50:50 disorder with Fe(III) at the inner position of the linking belt. Regarding the synthetic conditions of $\mathbf{F e - 1}$, which include the use of an acidic buffer ( $\mathrm{pH}=4.8$ ), the disorder with tungsten is in accordance with the results for the disordered alpha-arsenotungstate compounds observed at lower $\mathrm{pH}$ values, reported by Kortz et al. in 2001 [12] as well as the disordered Krebs-type tungstoantimonates recently reported by our group [10]. The peripheral iron centers exhibit a distorted octahedral coordination environment with one acetate ligand and one $\mathrm{H}_{2} \mathrm{O}$ molecule coordinated to the metal center and $\mathrm{Fe}-\mathrm{O}$ bond lengths ranging from 1.9271(1) at the inner site of the belt to 2.139(1) $\AA$ between the peripheral iron centers and the $\mathrm{H}_{2} \mathrm{O}$ ligand at the peripheral belt positions (Fig. 1).

Besides SXRD, Fe-1 was also characterized in the solid state by powder X-ray diffraction (PXRD) (Fig. S1), ATR-IR spectroscopy (Fig. 2), and elemental analysis.

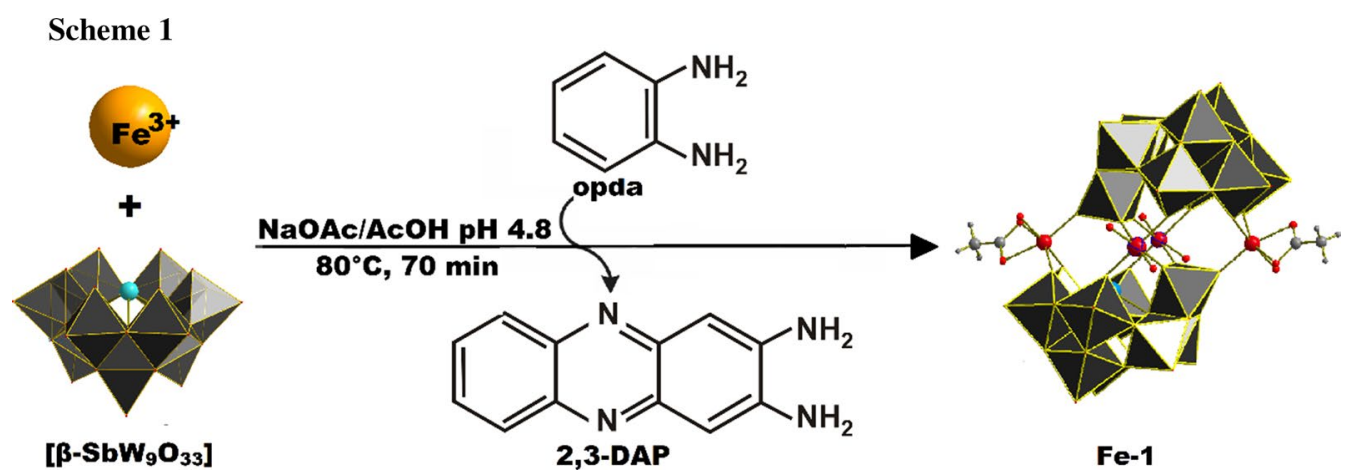

Scheme 1 Structure and synthesis of Fe-1. The synthesis starts from the $\left[\beta-\mathrm{SbW}_{9} \mathrm{O}_{33}\right]$ unit and $\mathrm{FeCl}_{3}$. Catalytic oxidation of opda by the in situ formed Fe-1 anion leads to formation of 2,3-diaminophenazinium (2,3-DAP) which acts as a counteraction for Fe-1. Counter cati- ons are omitted for clarity. Color legend: $\mathrm{WO}_{6}$, grey; $\mathrm{Sb}$, light blue; $\mathrm{Fe}$, light orange; disordered $\mathrm{Fe} / \mathrm{W}$ centers, light orange with dark blue stripes; $\mathrm{O}_{\mathrm{t}}$, red 
Fig. 1 Polyhedral representation of Fe-1. $\mathrm{WO}_{6}$, grey; $\mathrm{Sb}$, light blue; Fe, light orange; disordered $\mathrm{Fe} / \mathrm{W}$ centers, light orange with dark blue stripes; $\mathrm{O}_{\mathrm{t}}$, red; $\mathrm{C}$, light grey; $\mathrm{N}$, blue

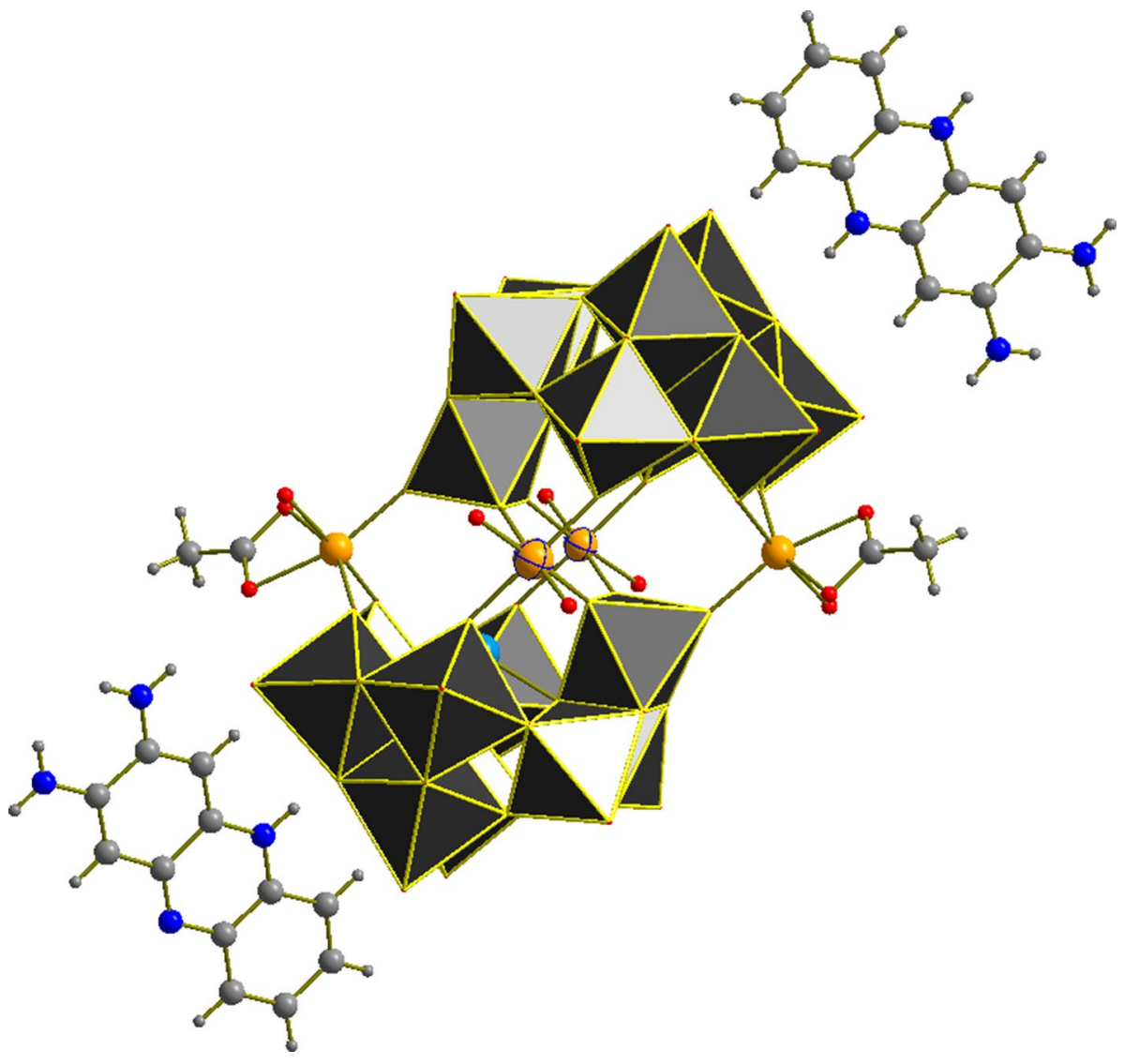

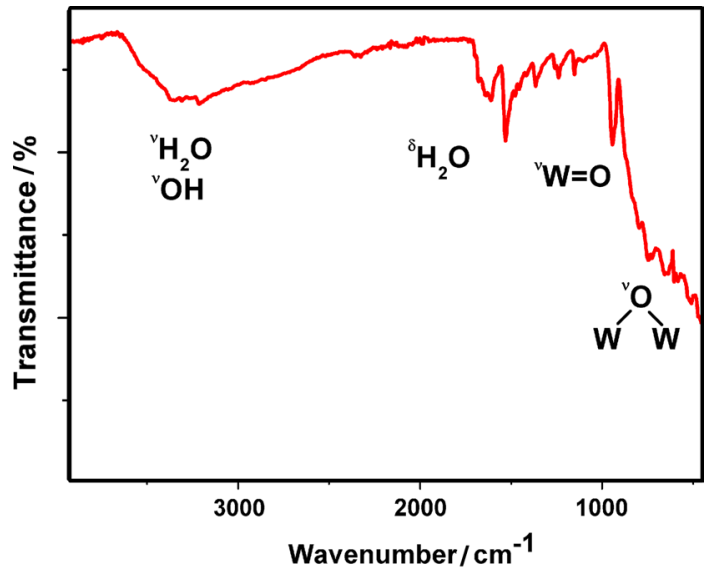

Fig. 2 IR spectrum of $\left(\mathrm{C}_{12} \mathrm{~N}_{4} \mathrm{H}_{11}\right)_{4} \mathrm{Na}_{2} \mathrm{H}_{5}\left[\left(\mathrm{Fe}\left(\mathrm{H}_{2} \mathrm{O}\right)_{3}\right)_{2}\left(\left(\mathrm{FeO}_{2}\right)_{0.5}(\mathrm{WO}\right.\right.$ $\left.\left.\left.{ }_{2}\right)_{0.5}\right)_{2}\left(\beta-\mathrm{SbW}_{9} \mathrm{O}_{33}\right)_{2}\right](\mathbf{F e}-\mathbf{1})$

\section{UV-Vis spectrum of Fe-1}

The UV-Vis spectrum of $\mathbf{F e}-\mathbf{1}$ exhibits two major peaks, one at $271 \mathrm{~nm}$ corresponding to the $\mathrm{p} \pi\left(\mathrm{O}_{\mathrm{b}}\right) \rightarrow \mathrm{d} \pi^{*}(\mathrm{~W})$ ligand-tometal charge-transfer transition typical for the Keggin-type framework [13], whereas a second absorption maximum at $423 \mathrm{~nm}$ can be attributed to the aromatic transitions of

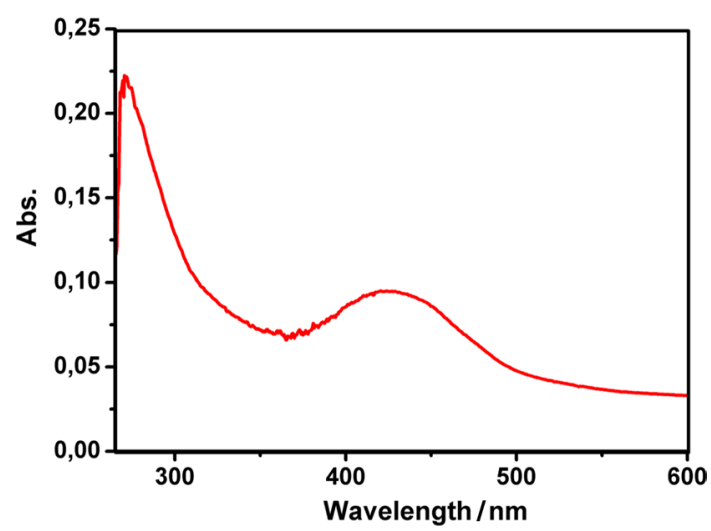

Fig. 3 UV-Vis-spectrum of Fe-1 $\left(5 \times 10^{-6} \mathrm{M}\right)$ in $10 \mathrm{mM} \mathrm{NaOAc}$ buffer $\mathrm{pH} 5.5$ showing typical $\mathrm{O} \rightarrow \mathrm{W}$ ligand-to-metal chargetransfer $(271 \mathrm{~nm})$ and aromatic transitions $(423 \mathrm{~nm})$

the 2,3-DAP counter cations present in the structure [14] (Fig. 3).

\section{POM-protein interactions}

Considering the known catalytic activity of $\mathrm{Fe}(\mathrm{III})$ as a Lewis acid, the POM-protein interactions of the peripheral $\mathrm{Fe}(\mathrm{III})$ metal centers of $\mathbf{F e}-\mathbf{1}$ with human serum albumin 
(HSA) as a model protein were investigated to assess whether Fe-1 exhibits any proteolytic activity. SDS-PAGE was performed on reaction mixtures of HSA and Fe-1 in a NaOAc buffer [10 mM] pH 5.5 to ensure a stable more accessible acidic conformation of the model protein [15]. The results revealed no hydrolytic activity of $\mathbf{F e - 1}$ towards the peptide bonds of the model protein even at $65^{\circ} \mathrm{C}$ and 100-fold excess of the POM compound indicated by intact protein bands at $66 \mathrm{kDa}$ (Fig. 4). This is in good accordance with our previous results reported for the isostructural manganese- and zinc-substituted DAP-POM derivatives [10].

\section{Conclusion}

In conclusion, the synthetic pathway presented in this work may open new perspectives for the preparation of novel Krebs-POM archetypes exhibiting unconventional counter cations. The interactions of the Krebs-POM compound Fe1 with HSA as a model protein have been investigated and the non-proteolytic behavior of Fe-1 may be interesting for further POM-protein interaction studies ultimately perhaps opening novel perspectives in the field of POM-assisted protein crystallography.

\section{Experimental}

All reagents were obtained commercially from Aldrich, of high-purity grade and were used as purchased without further purification. $\mathrm{Na}_{9}\left[B-\alpha-\mathrm{SbW}_{9} \mathrm{O}_{33}\right]$ was prepared according to the literature procedure reported by Bösing et al. [8]. X-ray intensity data were measured on a Bruker X8 APEX2 diffractometer equipped with a multilayer monochromator,
Mo K/ $\alpha$ INCOATEC micro focus sealed tube and Oxford cooling device. The following software was used: Bruker SAINT software package [16] using a narrow-frame algorithm for frame integration, OLEX2 [17] for structure solution, refinement, molecular diagrams and graphical user-interface, Shelxle [18] for refinement and graphical user-interface SHELXS-2013 [19] for structure solution, SHELXL-2013 [20] for refinement. Experimental data and the CCDC-Code are provided in Table S1. Crystal data, data collection parameters, and structure refinement details are given in Tables S2 and S3 of the electronic supporting information. X-ray powder diffraction measurements were performed on a Bruker D8 ADVANCE diffractometer, $\mathrm{Cu}$ $\mathrm{K} \alpha$ radiation, $\lambda=1.54,056 \AA$, LYNXEYE silicon strip detector and SolX energy dispersive detector, variable slit aperture with $12 \mathrm{~mm}, 5^{\circ} \leq 2 \theta \leq 40^{\circ}$. Attenuated total reflection Fourier-transform Infrared Spectroscopy: all spectra were recorded on a Bruker Tensor 27 IR Spectrometer equipped with a single-reflection diamond-ATR unit. Frequencies are given in $\mathrm{cm}^{-1}$, intensities denoted as $\mathrm{w}=$ weak, $\mathrm{m}=$ medium, $\mathrm{s}=$ strong. Elemental analysis $(\mathrm{C}, \mathrm{H}, \mathrm{N}, \mathrm{O})$ was performed at Mikroanalytisches Laboratorium, Fakultät für Chemie, Universität Wien using the $2400 \mathrm{CHN}$ Elemental Analyzer and the EA 3000, respectively. UV-Vis spectra were collected on a Shimadzu UV 1800 spectrophotometer. The spectra were recorded in $10 \mathrm{mM} \mathrm{NaOAc}$ buffer $\mathrm{pH}$ 5.5. SDS-PAGE was performed according to a standard procedure [21] using Precision Plus Protein Standard Dual Color (Bio-Rad) as molecular weight marker. Samples were applied to $14 \%$ polyacrylamide gels under reducing conditions. The sample amount loaded onto the gel was $5 \mu \mathrm{g}$. Gels were stained with Coomassie Brilliant Blue. Imaging of the gels was applied with Gel Doc ${ }^{\mathrm{TM}}$ XR of BIO-RAD. Human serum albumin (HSA) $(5 \mu \mathrm{g})$ was mixed with 1,10 , and 100 equivalents of
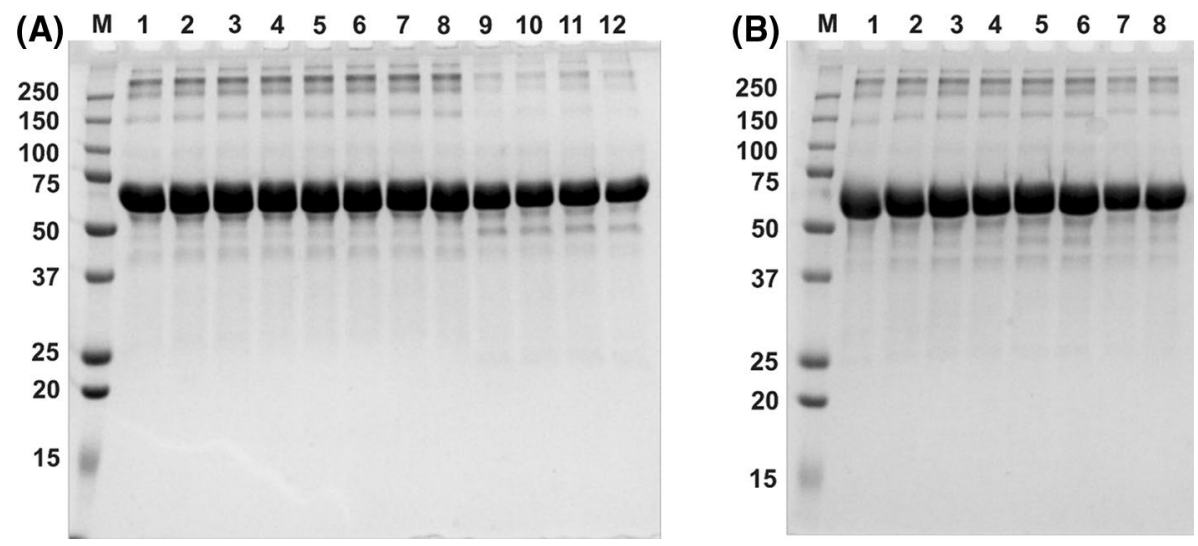

Fig. 4 HSA incubated with Fe-1 for $30 \mathrm{~min}$ at $20{ }^{\circ} \mathrm{C}(1-4)$, at $37{ }^{\circ} \mathrm{C}(5-8)$, and at $65{ }^{\circ} \mathrm{C}(9-12)$. 1) $5 \mu \mathrm{g}$ HSA without Fe-1, 2) 1:1 HSA:POM, 3) 1:10 HSA:POM, 4) 1:100 HSA:POM., 5) $5 \mu \mathrm{g}$ HSA without Fe-1, 6) 1:1 HSA:POM, 7) 1:10 HSA:POM, 8) 1:100
HSA:POM, 9) $5 \mu \mathrm{g}$ HSA without Fe-1, 10) 1:1 HSA:POM, 11) 1:10 HSA:POM, 12) 1:100 HSA:POM in NaOAc buffer [10 mM] $5.5 \mathrm{pH}$ A) HSA with Fe-1 after 30 min B) HSA with Fe-1 after 3 days 
Fe-1 in $10 \mathrm{mM} \mathrm{NaOAc}$ buffer pH 5.5 and incubated at three different temperatures $\left(20,37\right.$, and $\left.65^{\circ} \mathrm{C}\right)$.

$\left(\mathrm{C}_{12} \mathrm{~N}_{4} \mathrm{H}_{11}\right)_{4} \mathrm{Na}_{2} \mathrm{H}_{5}\left[\left(\mathrm{Fe}\left(\mathrm{H}_{2} \mathrm{O}\right)_{3}\right)_{2}\left(\left(\mathrm{FeO}_{2}\right)_{0.5}\left(\mathrm{WO}_{2}\right)_{0.5}\right)_{2}(\beta-\right.$ $\left.\left.\mathrm{SbW}_{9} \mathrm{O}_{33}\right)_{2}\right](\mathrm{Fe}-1)$ To a stirred solution of $215 \mathrm{mg}$ $\mathrm{Na}_{9}\left[B-\alpha-\mathrm{SbW}_{9} \mathrm{O}_{33}\right](0.05 \mathrm{mmol})$ in $20 \mathrm{~cm}^{3}$ aqueous sodium acetate buffer (0.5 M NaOAc/AcOH, pH 4.8), $81 \mathrm{mg} \mathrm{FeCl}_{3} \cdot 6$ $\mathrm{H}_{2} \mathrm{O}(0.3 \mathrm{mmol})$ was added. The resulting orange reaction mixture was stirred at $70{ }^{\circ} \mathrm{C}$ for $10 \mathrm{~min}$. ortho-Phenylenediamine (opda, $21 \mathrm{mg}, 0.2 \mathrm{mmol}$ ) was added to the reaction solution and the mixture was stirred for further $60 \mathrm{~min}$ at $85^{\circ} \mathrm{C}$. A color change from orange to dark red over the time period of 60 min was noticed. Dark red crystal plates of Fe1 were obtained upon cooling the filtered reaction mixture to room temperature and further evaporation at $18{ }^{\circ} \mathrm{C}$ gave a total yield of $60 \%$ based on $\mathrm{W}$ after 3 days. IR (ATR): $\bar{v}=3363.4(\mathrm{w}), 3260.6(\mathrm{w}), 1635.1(\mathrm{~m}), 1509.2(\mathrm{~m}), 1400.4$ (m), $1233.4(\mathrm{~s}), 1152.1(\mathrm{~s}), 935.8(\mathrm{~s}), 744.5(\mathrm{~s}) \mathrm{cm}^{-1}$.

Acknowledgements Open access funding provided by Austrian Science Fund (FWF). We gratefully acknowledge the Austrian Science Fund FWF (P27534) as well as the University of Vienna for financial support. E.T. and A.R. acknowledge the University of Vienna for awarding an Uni:docs fellowship to Elias Tanuhadi. Lastly, the authors wish to thank Nadiia Gumerova, PhD, Dipl.-Ing. Matthias Pretzler, Dr. Joscha Breibeck, Emir Al-Sayed, MSc and Ing. Alexander Roller for valuable discussions concerning this work.

Open Access This article is distributed under the terms of the Creative Commons Attribution 4.0 International License (http://creativeco mmons.org/licenses/by/4.0/), which permits unrestricted use, distribution, and reproduction in any medium, provided you give appropriate credit to the original author(s) and the source, provide a link to the Creative Commons license, and indicate if changes were made.

\section{References}

1. Pope MT (1983) Heteropoly and Isopoly oxometalates. SpringerVerlag, Berlin

2. Wang S, Yang GY (2015) Chem Rev 11:4893

3. Kastner K, Kibler AJ, Karjalainen E, Fernandes JA, Sans V, Newton GN (2017) J Mater Chem A 5:11577

4. Bijelic A, Aureliano M, Rompel A (2018) Chem Commun 54:1153

5. Bijelic A, Aureliano M, Rompel A (2019) Angew Chem Int Ed 58:2980

6. Bijelic A, Rompel A (2017) Acc Chem Res 50:1441

7. Bijelic A, Rompel A (2015) Coord Chem Rev 299:22

8. Bösing M, Loose I, Pohlmann H, Krebs B (1997) Chem Eur J 3:1232

9. Bösing M, Nöh A, Loose I, Krebs B (1998) J Am Chem Soc 120:7252

10. Tanuhadi E, Roller A, Giester G, Kampatsikas I, Rompel A (2018) Dalton Trans 47:15651

11. Boggon TJ, Shapiro L (2000) Structure 8:143

12. Kortz U, Al-Kassem NK, Savelieff MG, Al Kadi NA, Sadakane M (2001) Inorg Chem 40:4742

13. Bi L, Li B, Wu L, Bao W (2009) Inorg Chim Acta 362:3309

14. Zhou P, Liu H, Chen S, Lucia L, Zhan H (2011) Molbank 2011:M730

15. Dockal M, Carter DC, Rüker F (2000) J Biol Chem 275:3042

16. Bruker SAINT v7.68A Copyright (C) 2005-2016 Bruker AXS

17. Dolomanov OV, Bourhis LJ, Gildea RJ, Howard JAK, Puschmann H (2009) J Appl Cryst 42:339

18. Huebschle CB, Sheldrick GM, Dittrich B (2011) J Appl Cryst 44:1281

19. Sheldrick GM (1996) SHELXS. University of Göttingen, Göttingen, Germany

20. Sheldrick GM (1996) SHELXL. University of Göttingen, Göttingen, Germany

21. Laemmli UK (1970) Nature 227:680

Publisher's Note Springer Nature remains neutral with regard to jurisdictional claims in published maps and institutional affiliations. 